\title{
Changes in Aquaporin-2 Protein Contribute to the Urine Concentrating Defect in Rats Fed a Low-Protein Diet
}

\author{
Jeff M. Sands, ${ }^{*}$ Masahiro Naruse, ${ }^{*}$ Joely D. Jacobs, ${ }^{*}$ Josiah N. Wilcox, ${ }^{\ddagger}$ and Janet D. Klein ${ }^{\star}$ \\ $*$ Renal and ${ }^{\ddagger}$ Hematology Divisions, Department of Medicine, Emory University School of Medicine, Atlanta, Georgia 30322
}

\begin{abstract}
Low-protein diets cause a urinary concentrating defect in rats and humans. Previously, we showed that feeding rats a low $(8 \%)$ protein diet induces a change in urea transport in initial inner medullary collecting ducts (IMCDs) which could contribute to the concentrating defect. Now, we test whether decreased osmotic water permeability $\left(P_{f}\right)$ contributes to the concentrating defect by measuring $P_{\mathrm{f}}$ in perfused initial and terminal IMCDs from rats fed 18 or $8 \%$ protein for 2 wk. In terminal IMCDs, arginine vasopressin (AVP)stimulated osmotic water permeability was significantly reduced in rats fed $8 \%$ protein compared to rats fed $18 \%$ protein. In initial IMCDs, AVP-stimulated osmotic water permeability was unaffected by dietary protein. Thus, AVPstimulated osmotic water permeability is significantly reduced in terminal IMCDs but not in initial IMCDs. Next, we determined if the amount of immunoreactive aquaporin-2 (AQP2, the AVP-regulated water channel) or AQP3 protein was altered. Protein was isolated from base or tip regions of rat inner medulla and Western analysis performed using polyclonal antibodies to rat AQP2 or AQP3 (courtesy of Dr. M.A. Knepper, National Institutes of Health, Bethesda, MD). In rats fed $8 \%$ protein (compared to rats fed $18 \%$ protein): (a) AQP2 decreases significantly in both membrane and vesicle fractions from the tip; (b) AQP2 is unchanged in the base; and (c) AQP3 is unchanged. Together, the results suggest that the decrease in AVP-stimulated osmotic water permeability results, at least in part, in the decrease in AQP2 protein. We conclude that water reabsorption, like urea reabsorption, responds to dietary protein restriction in a manner that would limit urine concentrating capacity. ( $J$. Clin. Invest. 1996. 97:2807-2814.) Key words: water • aquaporin • vasopressin • low-protein diet • urine concentrating mechanism
\end{abstract}

Address correspondence to Dr. Jeff M. Sands, Emory University School of Medicine, Renal Division, 1364 Clifton Road, NE, Atlanta, GA 30322. Phone: 404-727-2435; FAX: 404-727-3425; E-mail: jsands@ emory.edu

Received for publication 27 November 1995 and accepted in revised form 2 April 1996.

Portions of this work have been published in abstract form (1995. $J$. Am. Soc. Nephrol. 6:329, and 1996. FASEB J. 10:A274) and presented at the 28th Annual Meeting of the American Society of Nephrology, 5-8 November 1995, San Diego, CA and Experimental Biology '96, 14-17 April 1996, Washington, DC).

J. Clin. Invest.

(C) The American Society for Clinical Investigation, Inc.

0021-9738/96/06/2807/08 \$2.00

Volume 97, Number 12, June 1996, 2807-2814

\section{Introduction}

Low-protein diets decrease urine concentrating ability in rats and humans (1-6). In rats fed a low-protein diet, maximal urine osmolality (after water deprivation and/or exogenous arginine vasopressin $[\mathrm{AVP}]^{1}$ administration) is reduced by $27-$ $48 \%(3,6)$. In healthy adult humans fed a low-protein diet, maximal urine osmolality was reduced from 1,000 to 750 $\mathrm{mOsm} / \mathrm{kg} \mathrm{H}_{2} \mathrm{O}(2,4)$. In patients with protein-calorie malnutrition, maximal urine osmolality was $450 \mathrm{mOsm} / \mathrm{kg} \mathrm{H}_{2} \mathrm{O}$ and increased to $755 \mathrm{mOsm} / \mathrm{kg} \mathrm{H}_{2} \mathrm{O}$ after protein repletion (5). In both rats and humans, the reduction in urine osmolality can be limited to a reduction in both urinary urea and nonurea solute concentrations $(1,3)$.

We previously showed that the adaptive response to a low (8\%)-protein diet includes induction of two urea transport processes, an AVP-stimulated facilitated urea transporter (79) and a sodium-dependent secondary active urea transporter $(7,10)$. Neither urea transport process is expressed in initial inner medullary collecting ducts (IMCDs) from rats fed a normal $(18 \%)$ protein diet. This response permits an increase in urea reabsorption across the initial IMCD by decreasing urea delivery to the deeper portions of the inner medulla and could contribute to the decrease in urine concentrating ability in rats fed a low-protein diet $(1,2,11,12)$.

Our previous studies also showed that the adaptive response to dietary protein restriction includes marked changes in initial IMCD principal cell ultrastructure (7) but does not include changes in $\mathrm{Na}^{+} / \mathrm{K}^{+}$-ATPase activity (10), aldose reductase, or sorbitol dehydrogenase activity (8). The purpose of the present study was to explore the specificity of the adaptive response to a low-protein diet. An inability to reabsorb water normally across the IMCD (and/or other collecting duct segments) could contribute to the decrease in urine concentrating ability. Consequently, we tested whether a second AVP-regulated transport function, water transport, may be altered by dietary protein restriction.

\section{Methods}

Tissue preparation. Pathogen-free male Sprague-Dawley rats (National Cancer Institute, Frederick, MD) were kept in filter-top cages with autoclaved bedding and received free access to water and either an 18 or $8 \%$ protein diet for $2 \mathrm{wk}$ (NIH-31 or NIH-31M, respectively; Ziegler Brothers, Gardner, PA). Rats fed this low-protein diet grow and maintain normal values of serum albumin, creatinine, total protein, and potassium $(3,7,8)$.

To measure urine output, rats were weighed, fed 18 or $8 \%$ protein diets for $2 \mathrm{wk}$, then reweighed and placed into metabolic cages. Water consumption and $24 \mathrm{~h}$ urine output were measured. Urine concentrating ability was assessed by measuring urine osmolality (model

1. Abbreviations used in this paper: AVP, arginine vasopressin; IMCD, inner medullary collecting duct; $A Q P$, aquaporin; $\mathrm{P}_{\mathrm{f}}$, osmotic water permeability; $\mathrm{L}_{\mathrm{p}}$, hydraulic permeability. 

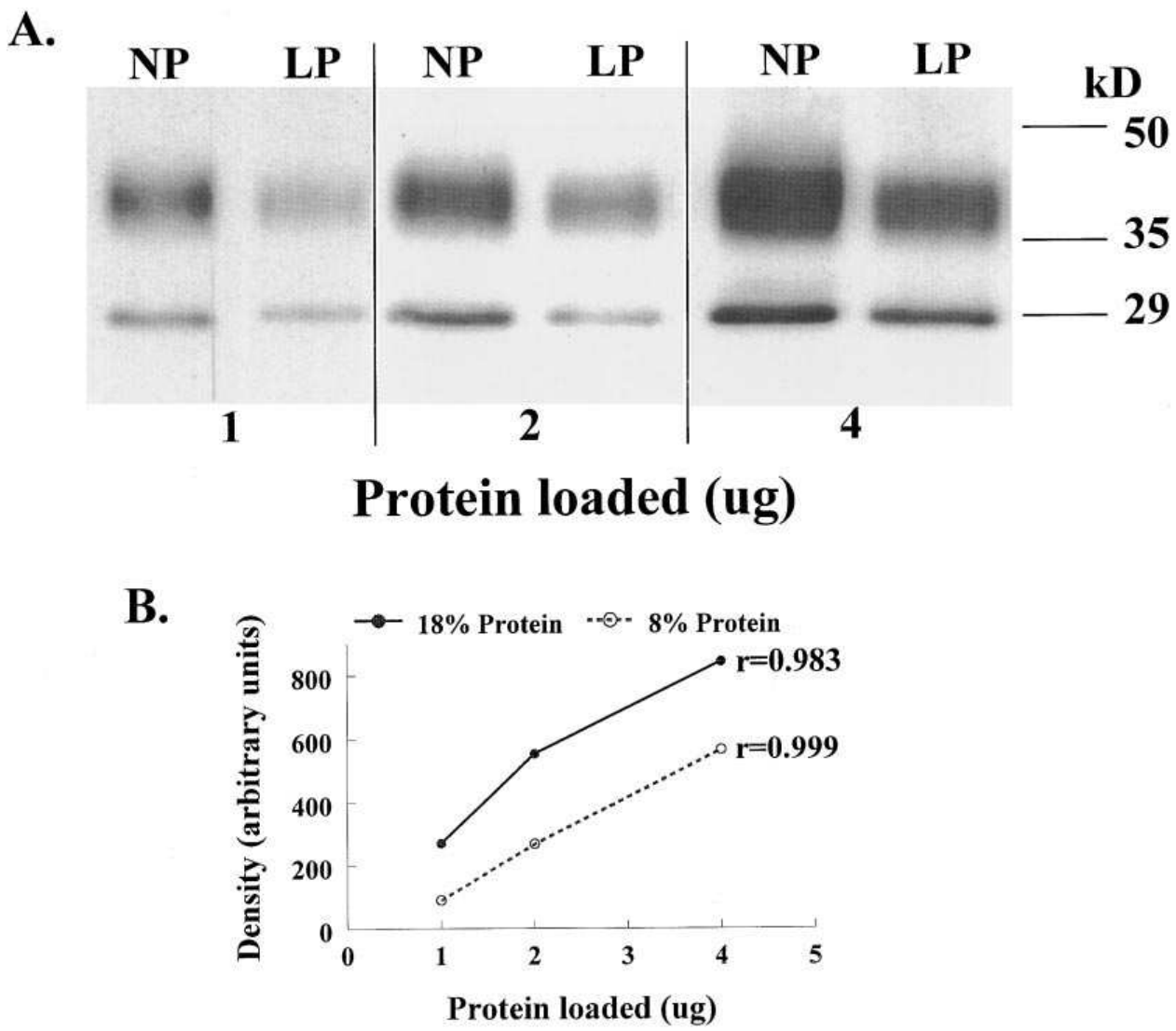

Figure 1. (A) Immunoblot of membrane fraction $(16,000 \mathrm{~g}$ pellet) from inner medullary tip from a rat fed $18 \%$ protein $(N P)$ and a rat fed $8 \%$ protein $(L P)$ and probed with AQP2 antibody. There is a band at $29 \mathrm{kD}$ and a broad band at $35-45 \mathrm{kD}$. Lanes were loaded with 1,2 , and $4 \mu \mathrm{g}$ protein. $(B)$ Summary of laser densitometric analysis. Density increases linearly with increasing amounts of protein loaded. Linear regression gives a correlation coefficient of $0.98-0.99$.

5500 osmometer; Wescor, Logan, UT) after $24 \mathrm{~h}$ of water deprivation.

Tissue preparation for tubule microperfusion. $20 \mathrm{~min}$ before each experiment, furosemide (5 mg i.p.) was administered (13). The kidneys were placed into chilled $\left(17^{\circ} \mathrm{C}\right)$, isotonic, dissecting solution to isolate initial or terminal IMCDs as described previously $(7,14)$. The dissecting solution was gassed with $95 \% \mathrm{O}_{2}$ and $5 \% \mathrm{CO}_{2}$ and contained (in mM): $\mathrm{NaCl} 118, \mathrm{NaHCO}_{3} 25, \mathrm{CaCl}_{2} 2, \mathrm{~K}_{2} \mathrm{HPO}_{4} 2.5, \mathrm{MgSO}_{4}$ 1.2, glucose 5.5, and creatinine 4. Initial IMCDs were dissected between the inner-outer medullary border (defined by the disappearance of thick ascending limbs) and the first bifurcation of collecting ducts within the inner medulla $(13,14)$. Terminal IMCDs were dissected between 50 and $70 \%$ of the distance from the inner-outer medullary junction and the papillary tip $(13,14)$. The tubules were perfused after transfer into a bath which was exchanged continuously at a rate of $1 \mathrm{ml} / \mathrm{min}$ and was bubbled with $95 \% \mathrm{O}_{2} / 5 \% \mathrm{CO}_{2}$ gas $(13,14)$. Solution osmolality was also measured.

Osmotic water permeability $\left(P_{f}\right)$ measurement. To determine $\mathrm{P}_{\mathrm{f}}$ in initial or terminal IMCDs, creatinine was used as a volume marker (7, 14-16). Creatinine concentration in perfusate, bath, and collected fluid was measured using a continuous-flow ultramicro-colorimeter as described $(7,14) . \mathrm{P}_{\mathrm{f}}$ was measured by increasing bath osmolality to $490 \mathrm{mOsm} / \mathrm{kg} \mathrm{H}_{2} \mathrm{O}$ by adding $\mathrm{NaCl}(14,17)$. The perfusion rate $\left(\mathrm{V}_{\mathrm{o}}\right)$ was calculated as: $V_{o}=V_{l}\left(\mathrm{Cr}_{l} / \mathrm{Cr}_{o}\right)$, where $\mathrm{Cr}_{\mathrm{o}}$ is the creatinine concentration in the perfusate, $\mathrm{Cr}_{1}$ the creatinine concentration in the collected fluid, and $\mathrm{V}_{\mathrm{o}}$ and $\mathrm{V}_{1}$ are as defined above. Fluid flux $\left(\mathrm{J}_{\mathrm{v}}\right)$ was calculated as: $J_{v}=V_{o}-V_{l}$. $\mathrm{P}_{\mathrm{f}}$ was calculated using the equation of AlZahid et al. (18) as described (14).

After three to four control collections, $100 \mathrm{pM}$ AVP was added to the bath. After $30 \mathrm{~min}$ (19), a second set of three collections with a stable $\mathrm{P}_{\mathrm{f}}$ value were obtained to assess the response to AVP.

Immunohistochemistry. Rat kidneys were fixed with $4 \%$ paraformaldehyde, immersed in $15 \%$ sucrose $/ \mathrm{PBS}$ at $4^{\circ} \mathrm{C}$, embedded in O.C.T. (Baxter Healthcare Corp., Deerfield, IL), frozen, and stored at $-80^{\circ} \mathrm{C}$. Each kidney was cut into $7.5-\mu \mathrm{m}$ sections using a cryostat (20-22). After fixing in acetone, the sections were blocked with $1 \%$ gelatin/PBS, and incubated with a primary antibody which was either a polyclonal rabbit anti-rat aquaporin (AQP) 2 or AQP3 antibody, generously provided by Dr. Mark A. Knepper (NIH, Bethesda, MD) $(23,24)$. Next, sections were incubated with secondary antibody (goat anti-rabbit $\operatorname{IgG}$ ), then with ABC-alkaline phosphatase (\#AK5000; Vector Laboratories, Inc., Burlingame, CA) and reacted with Vector Substrate I plus levamisole (\#SK5100; Vector Laboratories Inc.). The sections were lightly counterstained with hematoxylin.

Western blot analysis. Kidney inner medullae were dissected into two regions: $(a)$ base and $(b)$ tip, to correlate with locations of the initial and terminal IMCD, respectively, as previously described (9). Tissue dissected from both kidneys from a single rat were placed into an ice-cold isolation buffer (triethanolamine $10 \mathrm{mM}$, sucrose $250 \mathrm{mM}$, $\mathrm{pH}$ 7.6, leupeptin $1 \mathrm{mg} / \mathrm{ml}$, and PMSF $2 \mathrm{mg} / \mathrm{ml}$ ), homogenized using a Teflon ${ }^{\circledR}$ homogenizer, and frozen at $-80^{\circ} \mathrm{C}(23)$.

After thawing, a portion of the homogenate was diluted 1:1 with $1 \%$ SDS and used for Western analysis of total cell lysate. The remainder of the homogenate was centrifuged twice at 4,000 $\mathrm{g}$ for 15 $\min$ at $4^{\circ} \mathrm{C}$, and the two supernatants were pooled and recentrifuged at $16,000 \mathrm{~g}$ for $30 \mathrm{~min}$ (23-27), yielding the "low-speed" pellet that was resuspended in $200 \mu \mathrm{l}$ of the isolation buffer. Finally, supernatant was recentrifuged at 200,000 $\mathrm{g}$ for $60 \mathrm{~min}$ (24-27), yielding the "highspeed" pellet that was resuspended in $200 \mu$ l of the isolation buffer. The low-speed pellet was used because it contains primarily membrane proteins while the high-speed pellet was studied because it contains primarily protein from intracellular vesicles (24-27).

Total protein in each sample was measured by the Bradford method (Bio-Rad Laboratories, Richmond, CA). The remaining sample was microfuged at full speed for $3 \mathrm{~min}$, and the pellet was resuspended in $50 \mu \mathrm{l}$ of SDS-PAGE sample buffer and was heated at $60^{\circ} \mathrm{C}$ for $20 \mathrm{~min}$. Proteins were size-separated by SDS-PAGE on $15 \%$ Laemmli gels, electroblotted to PVDF membranes (Gelman Scien- 
Table I. Urine Parameters

\begin{tabular}{lcccc}
\hline Dietary protein & Weight* & $\begin{array}{c}\text { Urine } \\
\text { volume }\end{array}$ & $\begin{array}{c}\text { Water } \\
\text { intake }\end{array}$ & $\begin{array}{c}\text { Urine } \\
\text { osmolality }\end{array}$ \\
\hline & $g$ & $m l / d$ & $m l / d$ & $m O s m / \mathrm{kg} \mathrm{H}_{2} \mathrm{O}$ \\
$18 \%$ Protein $(n=3)$ & $143 \pm 3$ & $12 \pm 3$ & $20 \pm 3$ & $2,439 \pm 229$ \\
$8 \%$ Protein $(n=5)$ & $125 \pm 13$ & $9 \pm 2$ & $18 \pm 3$ & $1,570 \pm 54$ \\
& $P=\mathrm{NS}$ & $P=\mathrm{NS}$ & $P=\mathrm{NS}$ & $P<0.025$
\end{tabular}

* Rat weight was measured after 2 wk on diet; ${ }^{*}$ urine osmolality was measured after $24 \mathrm{~h}$ of water deprivation; data are mean $\pm \mathrm{SE}$.

tific, Ann Arbor, MI), and incubated for $30 \mathrm{~min}$ at room temperature with blocking buffer: $5 \%$ nonfat dry milk suspended in Tris-buffered saline (TBS: $20 \mathrm{mM}$ Tris $\mathrm{HCl}, 0.5 \mathrm{M} \mathrm{NaCl}, \mathrm{pH} 7.5$ ).

The Western blots were probed with polyclonal antibodies to AQP2 (23) or AQP3 (24) diluted 1:2,000 in TBS with $0.5 \%$ Tween-20 overnight at $4^{\circ} \mathrm{C}$, then washed $3 \times$ in TBS/Tween. Blots were then incubated with horseradish peroxidase-linked goat anti-rabbit IgG (dilution 1:5,000; Amersham International, Little Chalfont, UK) for $2 \mathrm{~h}$ at room temperature, washed twice with TBS/Tween, and bound antibody was visualized using chemiluminescence (ECL Western Blot kit; Amersham International).

Laser densitometry was used to quantitate the AQP signal. Total signal intensity was obtained by adding intensity of the two AQP bands (23). Results are expressed as arbitrary U/mg protein loaded. We loaded immunoblots probed for AQP2 with $3 \mu \mathrm{g}$ protein/lane based upon our initial dose-studies (Fig. 1) and (23). Immunoblots probed for AQP3 were loaded with $6 \mu \mathrm{g}$ protein/lane (24). Some samples were duplicated on each gel to compare the densitometric results of different gels.

Statistics. Data are presented as mean $\pm \operatorname{SE}(n)$, where $n$ indicates the number of rats studied. For the microperfusion experiments, data from three to four collections were averaged to obtain a single value from each experimental phase in each tubule. For comparisons between two groups, a Student's $t$ test or a Mann-Whitney u-test was used to test for statistical significance. For comparisons between more than two groups, an ANOVA was used to test for statistical significance, followed by a multiple comparison, protected $t$ test (28) to determine which groups were significantly different. The criterion for statistical significance was $P<0.05$.

\section{Results}

Urine studies. All rats weighed $60-65 \mathrm{~g}$ at the start of the study. There was no significant difference in weight, urine output, or water intake between rats fed 18 or $8 \%$ protein after 2 wk (Table I). After $24 \mathrm{~h}$ of water deprivation, urine osmolality was reduced by $36 \%$ in rats fed $8 \%$ protein compared to rats fed $18 \%$ protein (Table I).

Osmotic water permeability. In rats fed $8 \%$ protein for 2 wk, basal $\mathrm{P}_{\mathrm{f}}$ in terminal IMCDs was not significantly different from rats fed $18 \%$ protein (Fig. 2 A). AVP (100 pM) significantly increased $\mathrm{P}_{\mathrm{f}}$ in terminal IMCDs from rats fed 18 or $8 \%$ protein. However, the increase with 100 pM AVP was significantly lower in terminal IMCDs from rats fed $8 \%$ protein than from rats fed $18 \%$ protein.

In initial IMCDs from rats fed 18 or $8 \%$ protein (Fig. $2 \mathrm{~B}$ ), AVP (100 pM) significantly increased $P_{f}$. Basal and AVP-stimulated $\mathrm{P}_{\mathrm{f}}$ values were not significantly different between initial IMCDs from rats fed 18 or $8 \%$ protein.

\section{A. Terminal IMCD}

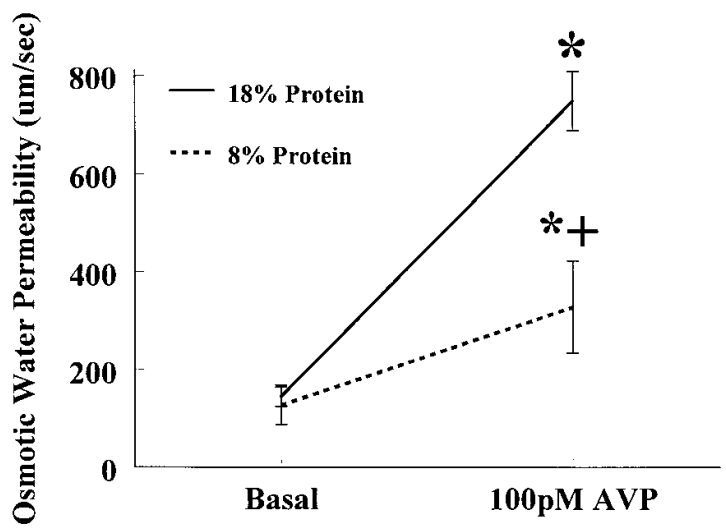

\section{B. Initial IMCD}

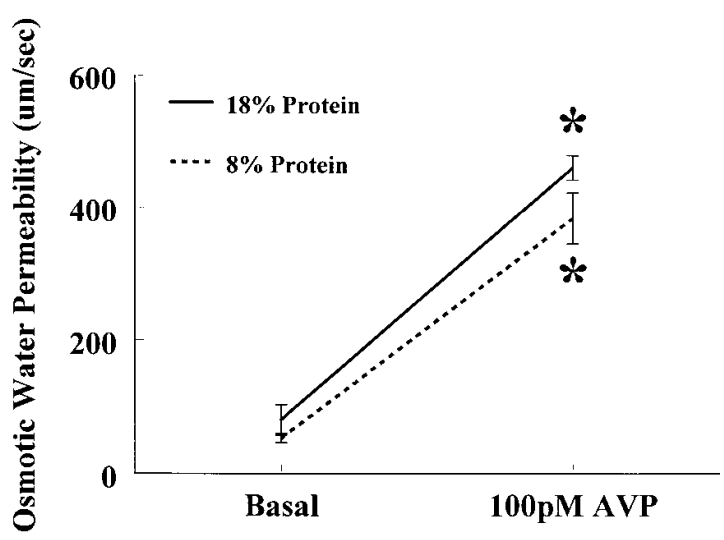

Figure 2. (A) In terminal IMCDs from rats fed $18 \%$ protein, $100 \mathrm{pM}$ AVP (added to the bath) significantly increased osmotic water permeability $\left(\mathrm{P}_{\mathrm{f}}\right)$. In terminal IMCDs from rats fed $8 \%$ protein; $100 \mathrm{pM}$ AVP increased $\mathrm{P}_{\mathrm{f}}$ significantly less than in rats fed $18 \%$ protein. $n=5$ tubules in each group; ${ }^{*} P<0.01$ vs. basal value; ${ }^{+} P<0.01$ between 18 and $8 \%$ protein. $(B)$ In initial IMCDs from rats fed 18 or $8 \%$ protein, $100 \mathrm{pM}$ AVP (added to the bath) significantly increased $\mathrm{P}_{\mathrm{f}} . n=$ 5 tubules in each group; $* P<0.01$ vs. basal value.

The perfusion flow rate was similar in each experimental condition. The values are provided in Table II.

Immunohistochemistry. Inner medulla from rats fed 18 or $8 \%$ protein for $2 \mathrm{wk}$ shows AQP2 staining localized to the IMCDs. Negative control studies (omission of the AQP2 pri-

Table II. Perfusion Rates

$$
\text { Basal }
$$
$100 \mathrm{pM}$ AVP

Terminal IMCDs

$18 \%$ Protein diet $(n=5)$

$8 \%$ Protein diet $(n=5)$

$21 \pm 1$

$24 \pm 2$

nitial IMCDs

$18 \%$ Protein diet $(n=5)$

$8 \%$ Protein diet $(n=5)$

$25 \pm 3$

$24 \pm 1$

$18 \pm 1$

Data are $\mathrm{nl} / \mathrm{min}$, mean $\pm \mathrm{SE}$. 
A.
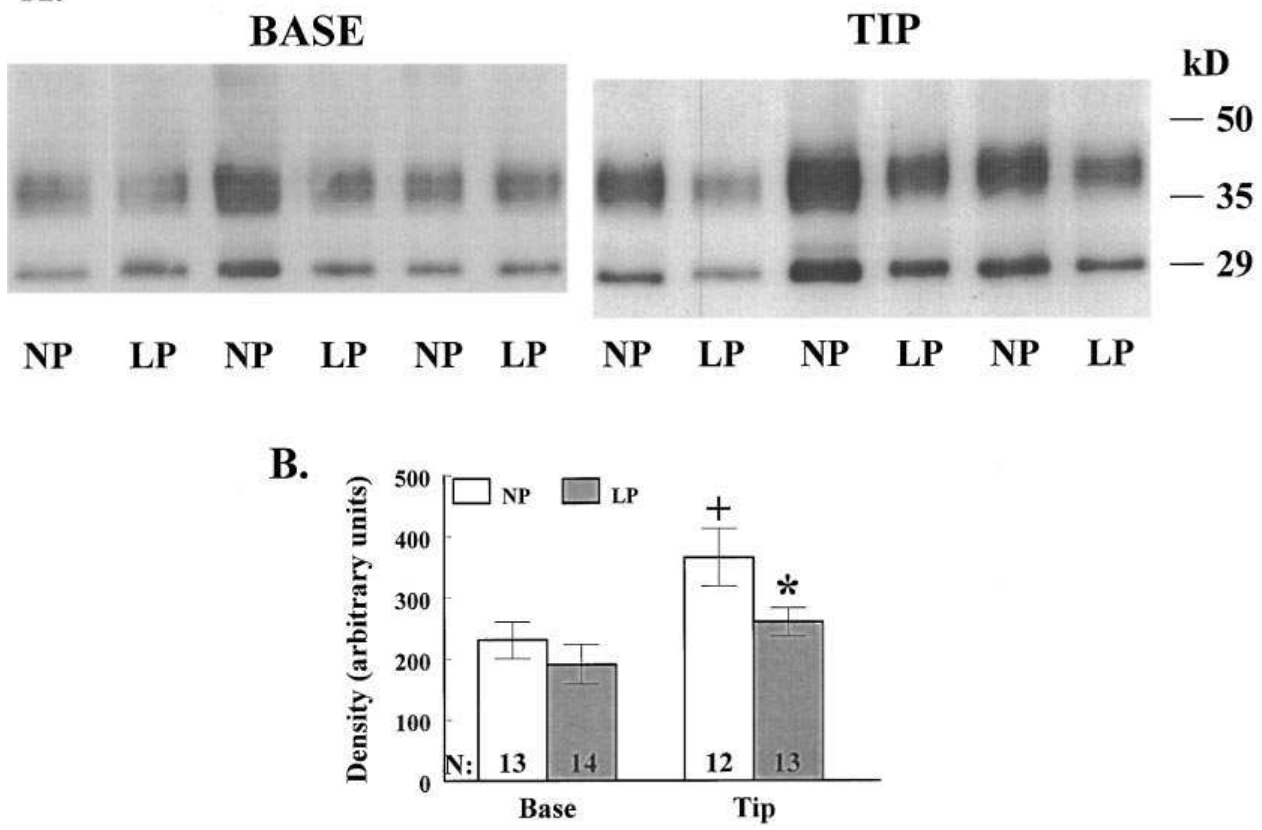

Figure 3. (A) Immunoblot of membrane fraction $(16,000 \mathrm{~g}$ pellet) from inner medullary base and tip from rats fed $18 \%(N P)$ or $8 \%$ $(L P)$ protein and probed with AQP2 antibody. There is a band at $29 \mathrm{kD}$ and a broad band at 35-45 $\mathrm{kD}$. Each lane shows protein from an individual rat. (B) Summary of laser densitometric analysis. AQP2 protein in the tip region from rats fed $18 \%$ protein $(N P)$ is significantly increased compared to the tip region from rats fed $8 \%$ protein $(L P)$ and from the base region of rats fed $18 \%$ protein. $N$ indicates number of rats in each group; $* P<0.0518$ vs. $8 \%$ protein; ${ }^{+} P<0.05$ base vs. tip.

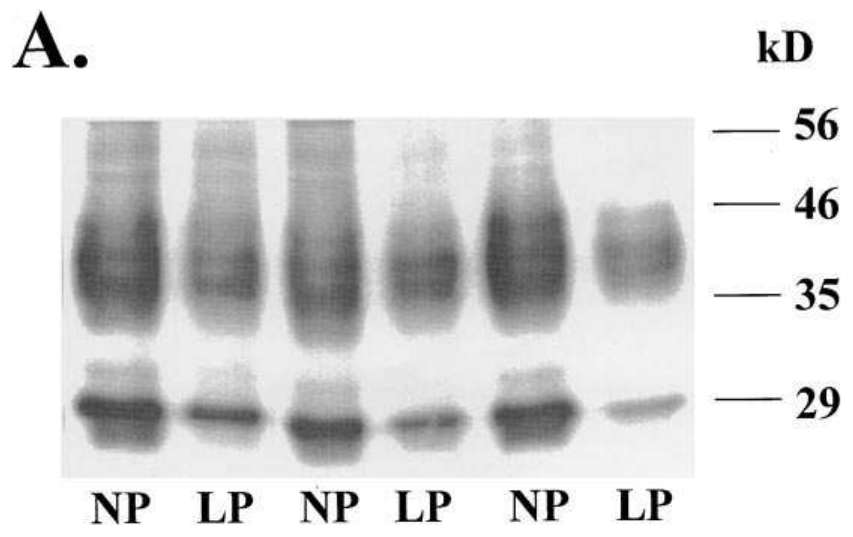

mary antibody) show no staining. Inner medulla from rats fed 18 or $8 \%$ protein shows AQP3 staining localized to the IMCDs. Negative control studies (omission of the AQP3 primary antibody) show no staining.

Western blot analysis of $A Q P 2$. In both the inner medullary base and tip from rats fed 18 or $8 \%$ protein for $2 \mathrm{wk}$, immunoblots of protein from the membrane fraction $(16,000 \mathrm{~g}$ pellet) probed using the AQP2 antibody show a band at $29 \mathrm{kD}$ and a broad band at $35-45 \mathrm{kD}$ (Fig. $3 A$ ). In the base region, laser densitometry (Fig. $3 B$ ) showed no significant difference in these bands between rats fed 18 and $8 \%$ protein. However, in the tip region, rats fed $8 \%$ protein had a $29 \%$ lower level of immunoreactive AQP2 protein $(P<0.05)$ on average. In addition, the amount of immunoreactive AQP2 protein was $60 \%$ higher $(P<0.05)$ on average in the tip than in the base region in rats fed $18 \%$ protein, but not in rats fed $8 \%$ protein.

Immunoblots of inner medullary tip protein from the vesicle fraction $(200,000 \mathrm{~g}$ pellet) and probed using the AQP2 antibody show bands at 29 and 35-45 kD (Fig. $4 A$ ). Laser densitometry showed that rats fed $8 \%$ protein had a $36 \%$ lower level of AQP2 protein $(P<0.05$, Fig. $4 B)$ on average.

Immunoblots of inner medullary tip proteins from total cell lysate and probed using the AQP2 antibody show bands at 29 and $35-45 \mathrm{kD}$ (Fig. $5 \mathrm{~A}$ ). Fig. $5 \mathrm{~B}$ shows a Coomassie bluestained gel run in parallel which shows no obvious difference between rats fed 18 or $8 \%$ protein, indicating that the differences in immunoreactive AQP2 (Fig. $5 A$ ) were not due to a difference in the loading of the gel. Laser densitometry showed that rats fed $8 \%$ protein had a $32 \%$ lower level of AQP2 protein $(P<0.05$, Fig. $5 C)$ on average.

Western blot analysis of AQP3. Immunoblots probed using the AQP3 antibody show a band at $27 \mathrm{kD}$ and a broad band at $33-40 \mathrm{kD}$ in protein from the membrane fraction $(16,000 \mathrm{~g}$ pel-

Figure 4. (A) Immunoblot of vesicle fraction $(200,000 \mathrm{~g}$ pellet) from inner medullary tip from rats fed $18 \%(N P)$ or $8 \%(L P)$ protein and probed with AQP2 antibody. There is a band at $29 \mathrm{kD}$ and a broad band at 35-45 kD. Each lane shows protein from an individual rat. (B) Summary of laser densitometric analysis. AQP2 protein in the tip

region from rats fed $18 \%$ protein $(N P)$ is significantly increased compared to the tip region from rats fed $8 \%$ protein $(L P) . n=4$ rats in each group; $* P<0.05$. 


\section{A. AQP2 Immunoblot}

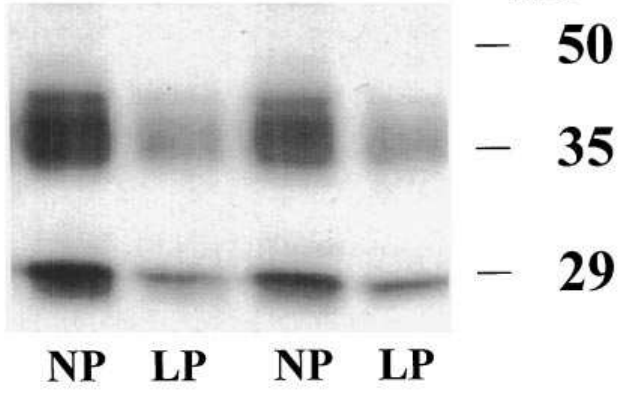

B. Coomassie Blue

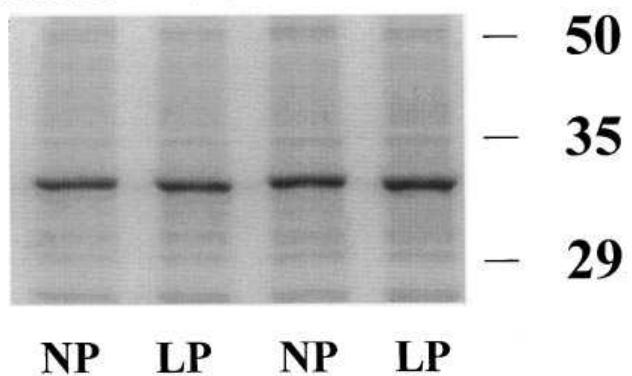

C.

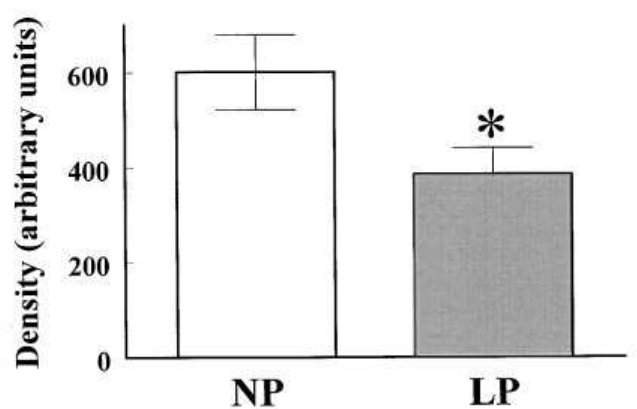

Figure 5. (A) Immunoblot of proteins from total cell lysate from inner medullary tip from rats fed $18 \%(N P)$ or $8 \%(L P)$ protein and probed with AQP2 antibody. There is a band at $29 \mathrm{kD}$ and a broad band at 35-45 kD. Each lane shows protein from an individual rat. $(B)$ Coomassie blue-stained gel of proteins from total cell lysate from inner medullary tip from rats fed $18 \%(N P)$ or $8 \%(L P)$ protein which was run in parallel with the immunoblot in panel $A$. Each lane shows protein from an individual rat. There is no obvious difference in the amount of protein loaded or between rats fed 18 or $8 \%$ protein (C) Summary of laser densitometric analysis. AQP2 protein in the tip region from rats fed $18 \%$ protein $(N P)$ is significantly increased compared to the tip region from rats fed $8 \%$ protein $(L P) . n=5$ rats in each group; $* P<0.05$.

let) of both the base and tip regions from rats fed 18 or $8 \%$ protein (Fig. $6 \mathrm{~A}$ ). There was no significant difference in the level of immunoreactive AQP3 protein in either the base or tip between rats fed 18 or $8 \%$ protein. Laser densitometry (Fig. 6 $B$ ) showed that immunoreactive AQP3 was $65 \%$ higher in the base than in the tip in rats fed $18 \%$ protein $(P<0.05)$ and was $74 \%$ higher in rats fed $8 \%$ protein $(P<0.05)$ on average.

\section{Discussion}

Our main results are that AVP-stimulated osmotic water permeability is significantly reduced in the terminal IMCD and immunoreactive AQP2 protein is significantly reduced in the tip of the inner medulla of rats fed a low (8\%)-protein diet for 2 wk. The percent reduction in AQP2 protein was similar in total cell lysate, membrane $(16,000 \mathrm{~g})$ fraction, and vesicle $(200,000 \mathrm{~g})$ fraction. Based upon the immunohistochemical localization of AQP2 in terminal IMCDs but not in thin limbs or vasa recta $(23,29-31)$, we believe that the reduction in osmotic water permeability we observed in perfused terminal IMCDs can be related to the reduction in AQP2 protein we observed in the tip of the inner medulla. Thus, there are at least two adaptations in rats fed a low-protein diet that reduce urine concentrating capacity: $(a)$ increased urea reabsorption across the initial IMCD (7-10) and $(b)$ decreased water reabsorption across the terminal IMCD.

Osmotic water permeability. We could find no previous reports detailing $\mathrm{P}_{\mathrm{f}}$ in rats fed a low-protein diet except for a study of the influence of protein malnutrition and the rats we studied were not malnourished. Kudo et al. (32) measured osmotic water permeability in terminal IMCDs from malnourished Wistar rats fed $6 \%$ protein for $3 \mathrm{wk}$ (these rats had lost $20 \%$ of their body weight). Kudo et al. found that basal hydraulic permeability $\left(\mathrm{L}_{\mathrm{p}}\right)$ was zero in malnourished rats as well as in rats fed $25 \%$ protein, but AVP-stimulated $\mathrm{L}_{\mathrm{p}}$ was significantly reduced at 2.2 and $22 \mathrm{pM} \mathrm{AVP}$ in the malnourished rats (32). Curiously, at 0.2 and $110 \mathrm{pM} \mathrm{AVP,} \mathrm{L}_{\mathrm{p}}$ in malnourished and normal Wistar rats were similar (32) and the authors did not determine the influence of changes in water transport protein(s). In the present study, we used a low (8\%) protein diet which does not cause malnutrition $(3,7,8)$ and confirmed there was no significant difference in weight between rats fed the 18 or $8 \%$ protein diet for 2 wk (Table I). Thus, the decrease in AVP-stimulated $\mathrm{P}_{\mathrm{f}}$ observed in this study must be a specific adaptive response to a low-protein diet, rather than a nonspecific response to malnutrition.

We, like others, found that rats fed a normal (18\%) protein diet have basal and AVP-stimulated $\mathrm{P}_{\mathrm{f}}$ values which are higher in terminal IMCDs than in initial IMCDs $(14,33,34)$. Feeding rats $8 \%$ protein did not change basal $\mathrm{P}_{\mathrm{f}}$ values in either IMCD subsegment, but the $8 \%$ protein diet led to significantly lower AVP-stimulated $P_{f}$ values in terminal IMCDs, but not in initial IMCDs. Since AVP-stimulated cyclic AMP production is unaffected by dietary protein restriction in either IMCD subsegment (8), the reduction in AVP-stimulated $P_{\mathrm{f}}$ must not be due to a reduced ability to produce cyclic AMP.

Aquaporin proteins. The aquaporin family of water channel proteins includes AQP2, the AVP-regulated water channel cloned by Fushimi et al. (35). Nielsen et al. prepared a polyclonal antibody to AQP2 which recognizes two bands: a 29-kD protein and a broader band between 35 and $45 \mathrm{kD}$ which is thought to be the glycosylated form of AQP2 (23). We found a similar band pattern by Western blot. AQP2 is located primarily in the apical plasma membrane and intracellular space of principal and IMCD cells along the entire collecting duct $(23,29)$.

The AQP3 water channel was cloned by Ishibashi et al. (36), Ma et al. (37), and Echevarria et al. (38). Ecelbarger et al. prepared a polyclonal antibody to AQP3 which recognizes two bands: a $27-\mathrm{kD}$ protein and a broader band between 33 and 40 $\mathrm{kD}$ protein which is thought to be the glycosylated form of 
BASE

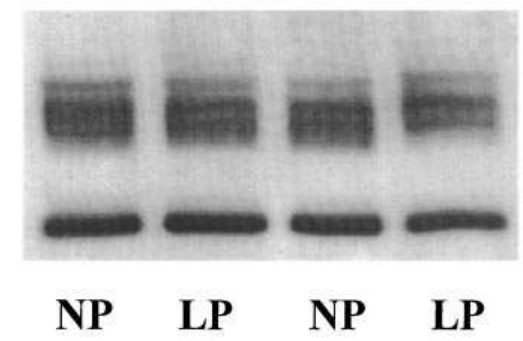

TIP

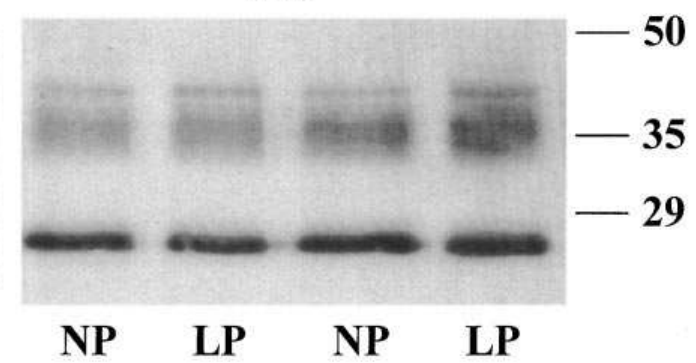

B.

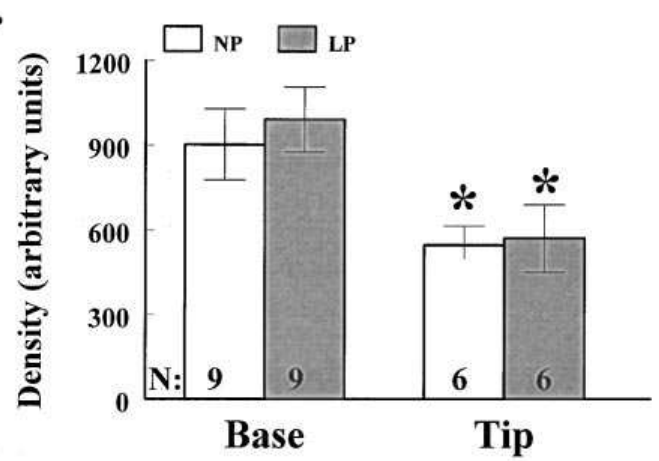

kD

Figure 6. (A) Immunoblot of membrane fraction $(16,000 \mathrm{~g}$ pellet) from inner medullary base and tip from rats fed $18(N P)$ or $8 \%$ $(L P)$ protein probed with AQP3 antibody. There is a band at $27 \mathrm{kD}$ and a broad band at 33-40 kD.

Each lane shows protein from an individual rat. (B) Summary of laser densitometric analysis. AQP3 protein in the base is significantly increased compared to the tip from rats fed $18 \%(N P)$ or $8 \%$ $(L P)$ protein. $N$ indicates number of rats in each group; $* P<0.05$ base vs. tip.
AQP3 (24). We found a similar band pattern by Western blot. AQP3 is located primarily in the basolateral plasma membrane of principal and IMCD cells in the medullary portions of the collecting duct $(31,36-39)$.

Regulation of AQP2 protein. Besides AVP, three mechanisms of regulation have been proposed for AQP2: (a) shuttling of preformed AQP2 between intracellular vesicles and the apical plasma membrane $(23,25,26,30)$; $(b)$ phosphorylation of AQP2; and $(c)$ variation in the amount of AQP2 protein. The first two mechanisms are thought to be involved in the acute response to AVP, while the latter mechanism may be important for chronic changes in concentrating ability. Regarding the first mechanism, we also found AQP2 protein in both plasma membrane and intracellular vesicle protein fractions. After acute administration of AVP, AQP2-containing vesicles fuse with the apical plasma membrane, but after withdrawing AVP, AQP2 is found in endocytosed vesicles $(26,30)$.

Regarding the second mechanism, Kuwahara et al. showed that APQ2 in Xenopus oocytes can be phosphorylated by protein kinase A (40). Whether phosphorylation occurs in the collecting duct and whether changes regulate water transport have not been tested.

In the present study, we tested whether the third mechanism is involved in the change in AVP-stimulated $P_{f}$ in terminal IMCDs from rats fed a low-protein diet. Previous studies show that variation in immunoreactive AQP2 protein levels can occur in rat models causing chronic changes in concentrating ability. For example, AQP2 protein is: $(a)$ increased by dehydration $(23) ;(b)$ increased by treating Brattleboro rats with $\operatorname{AVP}(31,41) ;(c)$ decreased in lithium-treated rats $(42) ;(d)$ decreased in hypokalemic rats (43); and (e) decreased by $\mathrm{V}_{2}$-receptor antagonists (44). We conclude that a decrease in AQP2 protein is involved in the response to a low-protein diet which also reduces concentrating ability.
In dehydrated rats, hypokalemic rats, and in AVP-treated Brattleboro rats, AQP2 protein expression changes in both the cortex and medulla, i.e. the change in AQP2 protein expression occurs along the entire collecting duct $(43,45)$. Thus unlike these other animal models, the response to a low-protein diet involves changes in AQP2 protein and AVP-stimulated $P_{f}$ only in the inner medullary tip and presumably the terminal IMCD.

We found that the percent reduction in inner medullary tip AQP2 protein was similar (29-36\%) in total cell lysate, plasma membrane proteins $(16,000 \mathrm{~g}$ pellet $)$, and intracellular vesicle proteins $(200,000 \mathrm{~g}$ pellet) in rats fed a low-protein diet. Since the percent reduction in AVP-stimulated $\mathrm{P}_{\mathrm{f}}(60 \%)$ in terminal IMCDs was greater than the percent reduction in AQP2 protein, we cannot exclude the possibility that a second mechanism may contribute to the functional reduction in AVP-stimulated $\mathrm{P}_{\mathrm{f}}$. One possibility is that there are differences in the size of the AQP2 pools between rats fed 18 and $8 \%$ protein. Alternatively, the reduction in AQP2 protein may impair its ability to form tetramers and transport water (46). Future studies will be needed to test these possibilities.

Regulation of AQP3 protein. Ecelbarger et al. (24) and Terris et al. (45) showed that dehydration increases AQP3 protein in the collecting duct. Terris et al. (45) also showed that treating Brattleboro rats with AVP increases AQP3 protein, but Yamamoto et al. (31) found no change in AQP3 protein. We found no change in AQP3 protein in either the inner medullary base or tip between rats fed 18 or $8 \%$ protein. Similar to the results of Ecelbarger et al. (24), we did find significantly less AQP3 protein in the tip compared to the base, but the physiologic significance of this difference is unknown.

Summary and perspective. A low (8\%) protein diet for $2 \mathrm{wk}$ reduces AVP-stimulated $P_{f}$ in terminal IMCDs but not in initial IMCDs. This decrease in AVP-stimulated $\mathrm{P}_{\mathrm{f}}$ is not due to a 
reduction in AVP-stimulated cyclic AMP production (8), but can be linked, at least in part, to a decrease in immunoreactive AQP2 protein in the inner medullary tip, specifically in the terminal IMCD. Since we found no change in AQP3 protein, the change in AQP2 protein is relatively specific. The localized change in AQP2 protein (terminal IMCD only) may represent an unique adaptation to a low-protein diet since other models causing chronic changes in urine concentrating ability involve changes in AQP2 protein along the entire collecting duct (45).

We propose that the urine-concentrating defect in rats fed a low-protein diet is due to $(a)$ an increase in urea reabsorption across the initial IMCD resulting in an inadequate delivery of urea to the tip of the inner medulla (7-10) and $(b)$ a decrease in AVP-stimulated osmotic water reabsorption across the terminal IMCD.

\section{Acknowledgments}

The authors thank Dr. Mark A. Knepper (National Institutes of Health) for his helpful discussions during the course of these studies and for generously providing the antibodies to AQP2 and AQP3, and Dr. William E. Mitch (Emory University) for his critical reading of this manuscript.

This work was supported by National Institutes of Health grants DK41707 and DK45688. J.M. Sands performed portions of this work during the tenure of an Established Investigatorship from the American Heart Association.

\section{References}

1. Gamble, J.L., C.F. McKhann, A.M. Butler, and E. Tuthill. 1934. An economy of water in renal function referable to urea. Am. J. Physiol. 109:139-154.

2. Levinsky, N.G., and R.W. Berliner. 1959. The role of urea in the urine concentrating mechanism. J. Clin. Invest. 38:741-748.

3. Peil, A.E., H. Stolte, and B. Schmidt-Nielsen. 1990. Uncoupling of glomerular and tubular regulations of urea excretion in rat. Am. J. Physiol. 258: F1666-F1674.

4. Epstein, F.H., C.R. Kleeman, S. Pursel, and A. Hendrikx. 1957. The effect of feeding protein and urea on the renal concentrating process. J. Clin. Invest. 36:635-641.

5. Klahr, S., and G.A.O. Alleyne. 1973. Effects of chronic protein-calorie malnutrition on the kidney. Kidney Int. 3:129-141.

6. Hendrikx, A., and F.H. Epstein. 1958. Effect of feeding protein and urea on renal concentrating ability in the rat. Am. J. Physiol. 195:539-542.

7. Isozaki, T., J.W. Verlander, and J.M. Sands. 1993. Low protein diet alters urea transport and cell structure in rat initial inner medullary collecting duct. $J$. Clin. Invest. 92:2448-2457.

8. Isozaki, T., A.G. Gillin, C.E. Swanson, and J.M. Sands. 1994. Protein restriction sequentially induces new urea transport processes in rat initial IMCDs. Am. J. Physiol. 266:F756-F761.

9. Ashkar, Z.M., S. Martial, T. Isozaki, S.R. Price, and J.M. Sands. 1995. Urea transport in initial IMCD of rats fed a low-protein diet: functional properties and mRNA abundance. Am. J. Physiol. 268:F1218-F1223.

10. Isozaki, T., J.P. Lea, J.A. Tumlin, and J.M. Sands. 1994. Sodium-dependent net urea transport in rat initial IMCDs. J. Clin. Invest. 94:1513-1517.

11. Pennell, J.P., V. Sanjana, N.R. Frey, and R.L. Jamison. 1975. The effect of urea infusion on the urinary concentrating mechanism in protein-depleted rats. J. Clin. Invest. 55:399-409.

12. Crawford, J.D., A.P. Doyle, and H. Probst. 1959. Service of urea in renal water conservation. Am. J. Physiol. 196:545-548.

13. Sands, J.M., and M.A. Knepper. 1987. Urea permeability of mammalian inner medullary collecting duct system and papillary surface epithelium. J. Clin. Invest. 79:138-147.

14. Sands, J.M., H. Nonoguchi, and M.A. Knepper. 1987. Vasopressin effects on urea and $\mathrm{H}_{2} \mathrm{O}$ transport in inner medullary collecting duct subsegments. Am. J. Physiol. 253:F823-F832.

15. Nonoguchi, H., J.M. Sands, and M.A. Knepper. 1988. Atrial natriuretic factor inhibits vasopressin-stimulated osmotic water permeability in rat inner medullary collecting duct. J. Clin. Invest. 82:1383-1390.

16. Knepper, M.A., D.W. Good, and M.B. Burg. 1985. Ammonia and bicarbonate transport by rat cortical collecting ducts perfused in vitro. Am. J. Physiol. 249:F870-F877.

17. Sands, J.M., and D.C. Schrader. 1991. An independent effect of osmolal- ity on urea transport in rat terminal IMCDs. J. Clin. Invest. 88:137-142.

18. Al-Zahid, G., J.A. Schafer, S.L. Troutman, and T.E. Andreoli. 1977. The effect of antidiuretic hormone on water and solute permeation, and the activation energies for these processes, in mammalian cortical collecting tubules. J. Membr. Biol. 31:103-130.

19. Nielsen, S., and M.A. Knepper. 1993. Vasopressin activates collecting duct urea transporters and water channels by distinct physical processes. Am. J. Physiol. 265:F204-F213.

20. Wilcox, J.N., K.M. Smith, S.M. Schwartz, and D. Gordon. 1989. Localization of tissue factor in the normal vessel and in the atherosclerotic plaque. Proc. Natl. Acad. Sci. USA. 86:2839-2843.

21. Wilcox, J.N., K.M. Smith, L.T. Williams, S.M. Schwartz, and D. Gordon. 1988. Platelet-derived growth factor mRNA detection in human atherosclerotic plaques by in situ hybridization. J. Clin. Invest. 82:1134-1143.

22. Martial, S., S.R. Price, and J.M. Sands. 1995. Regulation of aldose reductase, sorbitol dehydrogenase, and taurine cotransporter mRNA rat medulla. J. Am. Soc. Nephrol. 5:1971-1978.

23. Nielsen, S., S.R. DiGiovanni, E.I. Christensen, M.A. Knepper, and H.W. Harris. 1993. Cellular and subcellular immunolocalization of vasopressinregulated water channel in rat kidney. Proc. Natl. Acad. Sci. USA. 90:1166311667.

24. Ecelbarger, C.A., J. Terris, G. Frindt, M. Echevarria, D. Marples, S. Nielsen, and M.A. Knepper. 1995. Aquaporin-3 water channel localization and regulation in rat kidney. Am. J. Physiol. 269:F663-F672.

25. Nielsen, S., D. Marples, H. Birn, M. Mohtashami, N.O. Dalby, W. Trimble, and M. Knepper. 1995. Expression of VAMP2-like protein in kidney collecting duct intracellular vesicles. Colocalization with aquaporin-2 water channels. J. Clin. Invest. 96:1834-1844.

26. Marples, D., M.A. Knepper, E.I. Christensen, and S. Nielsen. 1995. Redistribution of aquaporin-2 water channels induced by vasopressin in rat kidney inner medullary collecting duct. Am. J. Physiol. 269:C655-C664.

27. Terris, J., C.A. Ecelbarger, D. Marples, M.A. Knepper, and S. Nielsen. 1995. Distribution of aquaporin-4 water channel expression within rat kidney. Am. J. Physiol. 269:F775-F785.

28. Snedecor, G.W., and W.G. Cochran. 1980. Statistical Methods. Iowa State University Press, Ames, IA. 217.

29. Fushimi, K., S. Sasaki, T. Yamamoto, M. Hayashi, T. Furokawa, S. Uchida, M. Kuwahara, K. Ishibashi, M. Kawasaki, I. Kihara, and F. Marumo. 1994. Functional characterization and cell immunolocalization of AQP-CD water channel in kidney collecting duct. Am. J. Physiol. 267:F573-F582.

30. Nielsen, S., C.-L. Chou, D. Marples, E.I. Christensen, B.K. Kishore, and M.A. Knepper. 1995. Vasopressin increases water permeability of kidney collecting duct by inducing translocation of aquaporin-CD water channels to plasma membrane. Proc. Natl. Acad. Sci. USA. 92:1013-1017.

31. Yamamoto, T., S. Sasaki, K. Fushimi, K. Ishibashi, E. Yaoita, K. Kawasaki, F. Marumo, and I. Kihara. 1995. Vasopressin increases AQP-CD water channel in apical membrane of collecting duct cells in Brattleboro rats. Am. J. Physiol. 268:C1546-C1551.

32. Kudo, L.H., M.H.M. Shimizu, A.C. Seguro, and A.S. Rocha. 1991. Renal concentrating defect in protein malnutrition: the role of the thick ascending limb of Henle and inner medullary collecting duct. Nephron. 57:156-163.

33. Lankford, S.P., C.-L. Chou, Y. Terada, S.M. Wall, J.B. Wade, and M.A. Knepper. 1991. Regulation of collecting duct water permeability independent of cAMP-mediated AVP response. Am. J. Physiol. 261:F554-F566.

34. Han, J.S., K.A. Thompson, C. Chou, and M.A. Knepper. 1992. Experimental tests of three-dimensional model of urinary concentrating mechanism. $J$. Am. Soc. Nephrol. 2:1677-1688.

35. Fushimi, K., S. Uchida, Y. Hara, Y. Hirata, F. Marumo, and S. Sasaki. 1993. Cloning and expression of apical membrane water channel of rat kidney collecting tubule. Nature (Lond.). 361:549-552.

36. Ishibashi, K., S. Sasaki, K. Fushimi, S. Uchida, M. Kuwahara, H. Saito, T. Furukawa, K. Nakajima, Y. Yamaguchi, T. Gojobori, and F. Marumo. 1994. Molecular cloning and expression of a member of the aquaporin family with permeability to glycerol and urea in addition to water expressed at the basolateral membrane of kidney collecting duct cells. Proc. Natl. Acad. Sci. USA. 91: $6269-6273$.

37. Ma, T., A. Frigeri, H. Hasegawa, and A.S. Verkman. 1994. Cloning of a water channel homolog expressed in brain meningeal cells and kidney collecting duct that functions as a stilbene-sensitive glycerol transporter. J. Biol. Chem. 269:21845-21849.

38. Echevarria, M., E.E. Windhager, S.S. Tate, and G. Frindt. 1994. Cloning and expression of AQP3, a water channel from the medullary collecting duct of rat kidney. Proc. Natl. Acad. Sci. USA. 91:10997-11001.

39. Frigeri, A., M.A. Gropper, C.W. Turck, and A.S. Verkman. 1995. Immunolocalization of the mercurial-insensitive water channel and glycerol intrinsic protein in epithelial cell plasma membranes. Proc. Natl. Acad. Sci. USA. 92: 4328-4331.

40. Kuwahara, M., K. Fushimi, Y. Terada, L. Bai, F. Marumo, and S. Sasaki. 1995. cAMP-dependent phosphorylation stimulates water permeability of aquaporin-collecting duct water channel protein expressed in Xenopus oocytes. J. Biol. Chem. 270:10384-10387.

41. DiGiovanni, S.R., S. Nielsen, E.I. Christensen, and M.A. Knepper. 1994. 
Regulation of collecting duct water channel expression by vasopressin in Brattleboro rat. Proc. Natl. Acad. Sci. USA. 91:8984-8988.

42. Marples, D., S. Christensen, E.I. Christensen, P.D. Ottosen, and S. Nielsen. 1995. Lithium-induced downregulation of Aquaporin-2 water channel expression in rat kidney medulla. J. Clin. Invest. 95:1838-1845.

43. Marples, D., J. Frøkiaer, J. Dorup, M.A. Knepper, and S. Nielsen. 1996. Hypokalemia-induced downregulation of aquaporin-2 water channel expression in rat kidney medulla and cortex. J. Clin. Invest. 97:1960-1968.

44. Hayashi, M., S. Sasaki, H. Tsuganezawa, T. Monkawa, W. Kitajima, K.
Konishi, K. Fushimi, F. Marumo, and T. Saruta. 1994. Expression and distribution of aquaporin of collecting duct are regulated by vasopressin V2 receptor in rat kidney. J. Clin. Invest. 94:1778-1783.

45. Terris, J., C.A. Ecelbarger, S. Nielsen, and M.A. Knepper. 1995. Longterm regulation of four aquaporin water channels in rat kidney: roles of vasopressin and medullary hypertonicity. J. Am. Soc. Nephrol. 6:330. (Abstr.)

46. Agre, P., G.M. Preston, B.L. Smith, J.S. Jung, S. Raina, C. Moon, W.B. Guggino, and S. Nielsen. 1993. Aquaporin CHIP: the archetypal molecular water channel. Am. J. Physiol. 265:F463-F476. 